\title{
A Research on the Teaching Reform of Basic Art Courses in Colleges
}

\author{
Lili Zhang \\ School of Art and Design, Lanzhou Jiaotong University, Lanzhou City, \\ Gansu Province, 730070, China
}

\begin{abstract}
The basic courses of art schools in colleges are an important part of the professional teaching. The task of cultivating innovative and skilled talents becomes more and more arduous, which brings a severe test to the teaching of basic art courses. Based on the author's learning and practical experience, this paper firstly analyzed the innovative ideas of the teaching reform of the basic art courses, then constructed the teaching reform innovative system of basic art courses. Finally, the article proposed the embedding methods of innovative elements in the teaching of basic art courses. The results of this paper can provide professional guidance for the subsequent professional courses and can cultivate students' self-learning ability, practical awareness, innovative thinking, teamwork and communication ability.

Keywords: Colleges; Art; Basic courses; Teaching reform
\end{abstract}

\section{Introduction}

Basic art courses refer to general basic courses, including sketch, color, plane composition, three-dimensional composition and color composition. During the period when China vigorously develops vocational education and comprehensively improves the teaching quality of higher vocational education, the reform and innovation of basic art courses has great significance for promoting the reform and development of art courses in higher vocational colleges and enhancing the teaching quality and talents cultivating quality[1]. This article made a deep research and practice of the teaching reform and 
innovation of basic design courses and proposed a new plan for the teaching reform and innovation of the construction of the integrated art courses, so as to promote the teaching reform of basic art courses and propose corresponding theories for accelerating the cultivation of innovative and skilled talents.

\section{An Innovative Thinking on the Teaching Reform of Basic Art Courses}

\subsection{To revise teaching objectives}

As the basic teaching content of the traditional art majors is tightly confined to the traditional sketch and basic mold-making training of the color, it is completely unconnected with the design content and confines students' creative thinking. The basic art courses mainly include the related aesthetic knowledge, the history of aesthetics, the law of formal beauty, graphic creativity and comprehensive design[2]. The teaching reform must be closely linked with the common characteristics of various specialties, which takes the cultivation of innovative talents as the purpose, takes the research direction of each major as the guidance and firmly grasps the bedding, convergence and basic role of basic design courses in professional design. Basic teaching curriculum should focus on the professional design theory, professional design skills, innovative thinking skills and professional practical ability.

The colleges should give full play to the role of basic teaching and integrate knowledge teaching, the improvement of students' innovative ability and the cultivation of students' overall quality, so as to achieve the multidimensional training of various abilities and skills, multiple majors and multiple disciplines, and similar majors and ways of learning and thinking in the same learning environment. Vertical and horizontal cross-training of knowledge and abilities in the basic disciplines cultivates students' multidisciplinary creative ability to improve and develop their knowledge, ability, quality and emotion. Ultimately, this will help students form personalized abilities of the career, employment and entrepreneurship, so that students will become the master of the fate of their career.

\subsection{To change the teaching concept}

Traditional teaching methods are obviously unable to meet the development of design teaching today. The connotation of art is being replaced by new ideas, new materials and new forms. Only teachers can truly understand and grasp the requirements of basic art courses, can they guide students to release their potential abilities in the training, which will pave the way for future professional training. The targeted teaching reform should reflect the necessary professional competence and artistic accomplishment of art modeling and should change the old basic teaching model which blindly follows the traditional painting teaching methods and neglects the convergence between the thinking and practice of 
professional design courses. In the process of inheritance and innovation, teachers should propose more scientific and complete creative teaching thinking to further clarify that the core of the design lies in innovation. The key of the basic design courses is to establish student-centered and teacher-led teaching methods and models based on exploration and research. The curriculum construction should focus on the cultivation of students' design and innovative way of thinking and the training of their awareness of the modeling and color ambiguity. Besides, teachers should train students to apply divergent thinking to surpass natural entities in an all-round and multiple-angle way, so that students can reveal the modeling law and discover the potential aesthetic value[3].

\section{The Teaching Reform Innovative System of Basic Art Courses}

We divide the basic art courses into four parts: the form of two-dimensional plane, the color and form of two-dimensional space, the monochromatic form of threedimensional space and the color of three-dimensional space. Besides, we make a clear curriculum design system for these four parts, so that students can understand the relationship between basic courses and design purposefully and from the shallower to the deeper. Teachers should set the relevant subject training to help students better understand and master the relevant knowledge. The construction of the integrated teaching reform innovative system of basic art courses consists of four parts and each part is independent, comprehensive and open[4]. They also have a very close cross-linking structure which makes the teaching more compact, flexible and closely linked. The content of the new curriculum is diversified, epochal and scientific. We should not confine the basic courses and should design the curriculum according to students' practical problems. Moreover, we should integrate and synthesize the basic design courses and break the limitation of the traditional modeling basic courses to improve students' design thinking and practical comprehensive quality. Therefore, the teaching reform of basic disciplines can have a close relation with each major to adapt to professional characteristics and interests of different students.

The practice of teaching reform in the basic teaching of art design is conducive to promoting the benign development of other art majors. The system requires the completion of these courses in the first and second year, which fully embodies the guiding ideology of the basic teaching reform. This teaching plan takes the integration of the basic design sketches, design colors and the characteristics of various majors as a breakthrough to train students' innovative spirit and practical ability. According to the requirements of the new curriculum standards and the new syllabus, teachers should take the concept that students are subjects in the teaching as the guiding teaching ideology combining with the characteristics of the new textbooks. The course construction of each part is based on the knowledge theoretical framework. The new teaching system integrates the basic modeling courses, the design sketch and the design color courses closely[5]. In 
the key and difficult stage of the course, teachers can arrange corresponding discussion and research of a special topic. It is easier for the topic training to stimulate students' enthusiasm to explore some problems and improve their creative consciousness.

\section{The Embedding Methods of Innovative Elements in the Teaching of Basic Art Courses}

\subsection{To deepen curriculum reform with innovative ideas}

The innovation of the teaching research of basic art courses is to critically absorb the advanced experience of the predecessors and the world. According to the characteristics of the basic art courses in China and the actual situation of students, colleges should take the innovative ideas as the thought, deepen the reform of curriculum system, explore creative thinking and integrate multidisciplinary teaching methods to stimulate students' creativity and imagination[6]. Besides, in this system, students can acquire an ability to produce unique and innovative products with social or personal value. Curriculum reform seeks to create an effective curricular system for the creation of theoretical research and teaching reform in art majors. Based on this concept, this integrated educational reform system is scientific, practical, comprehensive and applicable. In addition, in the design process of the course, teachers should arrange practical teaching cases which is suitable for the basic design courses and should reflect the theory and practice in the classroom teaching fully and comprehensively to highlight the practical significance and application value of the teaching reform. The adjustment, innovation and optimization of the basic art courses can lead the innovation of the teaching practice in other art majors and highlight the professional innovative thinking and overall concept, which will fully integrate the intercourse and connection between these professional courses, so as to advance the all-round reform of the whole teaching.

\subsection{To strengthen the cultivation of students' creative thinking and design ability}

At present, the core of teaching reform of art education in China is to inspire students'

extension of their creative thinking and cultivate their design ability. The reform focuses on changing the model which just teaches skills and pays attention to cultivating students' creativity and application ability to build a fundamental education system which cultivates innovative art talents. Through the research and practice of the reform of basic art courses, teachers should enhance students' modeling ability, broaden their artistic vision and cultivate their professional quality of design and creativity[7]. The teaching reform research is based on the student-oriented and teacher-led exploration and research, and uses a variety of ways of thinking to cultivate students' keen observation ability, profound analysis 
ability, rich performance ability and innovative thinking ability. Therefore, students can master the modeling design laws and methods, and tap their potential, so that they can advance from the basic design learning to the cultivation of creative ideas, and gain creativity and inspiration from the practice. Colleges should actively set up discussion-based teaching, change the traditional teaching model and guide students to develop their creative thinking and potential. Besides, teachers should cultivate students' expressive force of features of perceived things, so that they can use the design vision and design ideas to express it. Moreover, colleges should cultivate students' keen observation and discovery ability, and organize students to train and study the visual expression. To this end, students can find the creative expression that suits their individual characteristics with the organic integration of their imagination and expression.

\section{Conclusion}

The reform and innovation of the basic curriculum is an important part of the reform of art courses in colleges. The art major should actively cooperate with industries and enterprises to develop the basic courses. According to the requirements of the design technical fields and professional posts, colleges should reform the basic curriculum system and teaching content, and establish curriculum standards which highlight the cultivation of vocational abilities. Meanwhile, colleges should strengthen the construction of teaching staff to improve the quality of the basic art courses, enhance the teaching quality of art majors and strengthen the personnel training quality.

\section{Acknowledgement}

This paper was supported by following items:

Youth Research Foundation of Lanzhou Jiaotong University: Enlightenment and application of comparative study of art design education between Gansu and American Universities(No.2015059).

Undergraduate teaching reform project in Lanzhou Jiaotong University, 2015: Study on teaching method of the basic course of art design major "Sketch" .

Research achievements of Educational Science Planning in Gansu Province(GS [2015] GHB0180)

\section{References}

[1] Yu Xin. A Discussion on the Reform of the Basic Compute Courses in Art Majors. Software, (07), pp.68-70, 2015.

[2] Du Bing, Zhang Jianshe. A Research of the Study and Practice of the Teaching Reform of Basic Art Courses. Journal of Agricultural University of 
Hebei (Agriculture and Forestry Education Edition), (03), pp.73-76, 2014.

[3] Liu Fuyuan. A Study on the Teaching of Basic Art Courses in Higher Vocational Colleges. Stage, (09), pp.191-192, 2013.

[4] Zhao Yuanjing. An Analysis of the Teaching of Basic Art Courses. Art Education Research, (09), pp.148-149, 2012.

[5] Chen Wei. A Study on the Teaching Reform of Basic Art Courses. Shanghai Artists, (04), pp.76-77, 2011.

[6] Lu Feiran. An Analysis of the Reform of Basic Architectural Modeling Courses. Art and Design (Theory), (10), pp.130-132, 2010.

[7] Liu Zhongmei. A Study on the Reform and Innovation of Basic Art Courses in Higher Vocational Education. Art Panorama, (02), pp.160-161, 2009. 